ДОСЛІДЖЕННЯ ЗАДОВОЛЕНОСТІ ЖИТТЯМ ЖІНОК-ТРУДОВИХ МІГРАНТОК В ІТАЛІЇ

\title{
THE INVESTIGATION OF LIFE SATISFACTION OF WOMEN LABOR MIGRANTS IN ITALY
}

удК 159.9.01 (331.556.4)

DOI https://doi.org/10.32843/2663-

5208.2020.16.41

\section{шелемей О.п.}

к.психол.н.,

доцент кафедри психіатрії, наркології

та медичної психології

Івано-Франківський національний

медичний університет

\begin{abstract}
у статті висвітлено психологічні аспекти трудової міграції. Проаналізовано теоретичні основи дослідження задоволеності життям трудових мігрантів. Задоволеність життям визначається як когнітивний компонент суб'єктивного благополуччя, а також як глобальна оцінка реального життя через призму суб'єктивних стандартів «хорошого життя». Відзначено, що трудова міграція може розглядатися як один із способів відновлення суб'єктивного благополуччя. Досліджено чинники, що впливають на загальну задоволеність життям трудових мігрантів. Представлено результати емпіричного дослідження задоволеності життям жінок-трудових мігранток в Італії. У ході опитування використано методику «Шкала задоволеності життям» Е. Дінера. Вказана методика вимірює когнітивну оцінку відповідності життєвих обставин очікуванням індивіда і відображає загальну міру внутрішньої гармонії і психологічної задоволеності. Вибірку дослідження склали 200 жінок - трудових мігранток віком від 30 до 79 років. Емпіричне дослідження проводилось в Північній Італії протягом 2018-2019 років. Встановлено, що кількість задоволених та незадоволених своїм життям жінок суттєво не відрізняється. Трудова міграція призводить до значущих змін у житті вимушених трудових мігрантів, може як покращувати, так і погіршувати якість їх життя. Констатовано, що задоволеність життям у жінок-трудових мігранток $є$ різною залежно від рівня освіти та терміну перебування в Iталії. Виявлено, що тенденція до задоволеності життям прослідковується у жінок із середньою та вищою освітами та тих, що перебували в Італії від 5 до 14 років. Показано, що тенденція до незадоволеності життям прослідковується у жінок із середньою спеціальною та вищою освітами, а також тих, які працювали в Iталії більше 10 років. Даний етап є першим у визначеній нами стратегії дослідження психологічного благополуччя жінок-трудових
\end{abstract}

мігранток. У подальшому планується продовження його вивчення.

Ключові слова: задоволеність життям, суб'єктивне благополуччя, шастя, трудова міграція, жінки трудові-мігрантки.

The article highlights the psychological aspects of labor migration. The theoretical bases of the investigation of life satisfaction of migrant workers are analyzed. Life satisfaction is defined as a cognitive component of subjective well-being, as well as a global assessment of real life through the prism of subjective standards of "good living". It is noted that labor migration can be considered as one of the ways to restore subjective well-being. Factors influencing the overall life satisfaction of migrant workers have been studied. The results of an empirical study of life satisfaction of women labor migrants in Italy are presented. E. Diner's "Life Satisfaction Scale" method was used in the survey. This technique measures the cognitive assessment of the relevance of life circumstances to the expectations of the individual and reflects the general measure of inner harmony and psychological satisfaction. The study sample consisted of 200 migrant women aged 30 to 79 years. An empirical study was conducted in Northern Italy during 2018-2019. It was found that the number of satisfied and dissatisfied with their lives women did not differ significantly. It was stated that the life satisfaction among women migrant workers varies depending on the level of education and length of stay in Italy. It was found that the tendency to life satisfaction is observed in women with secondary and higher education and those who were in Italy from 5 to 14 years. It is shown that the tendency to dissatisfaction with life is observed in women with secondary special and higher education, as well as those who have worked in Italy for more than 10 years. This stage is the first in our strategy of investigation of psychological well-being of migrant women. In the future it is planned to continue its study. Key words: life satisfaction, subjective well-being, happiness, labor migration, women labor migrants.
Постановка проблеми. Масова трудова міграція українців за кордон в останні роки набула масштабів національного лиха. Під трудовою міграцією слід насамперед вважати переміщення індивідів у просторі з метою підвищення рівня життя на основі вигіднішого використання власної робочої сили без зміни постійного місця проживання [3, с. 8]. Італія $€$ однією з популярних країн, куди прямують на заробітки українські громадяни. За останніми офіційними даними в Італії налічується близько 237 тисяч українців. Це четверта за розміром спільнота мігрантів [26]. Українська громада в Італії суттєво відрізняється від інших емігрантських спільнот за статевим розподілом: близько $80 \%$ становлять жінки, здебільшого віком від 50 і більше років. В основному українські жінки працюють на роботах, які не вимагають високої кваліфікації: доглядають за хворими і людьми похилого віку, а також допомагають по господарству [1, с. 107]. Напружена робота і часто відсутність відповідної соціальної підтримки призводять до непоправних психоемоційних 
втрат жінок, а відтак і до погіршення психічного здоров'я.

Аналіз останніх досліджень та публікацій. Проблеми, пов'язані з трудовою міграцією жінок, здебільшого розглядаються в площині соціологічного та економічного аналізу. I досі бракує досліджень та практично-методологічних напрацювань, які б ставили в центр уваги психологічні проблеми та наслідки цього явища. Психологічні аспекти трудової міграції у своїх працях розглядали О.Є. Блинова, О.З. Лютак, А.Л. Ковальчук, О.А. Малиновська. Здоров'я трудових мігрантів з точки зору таких негативних симптомів як депресивний настрій, емоційні проблеми, посттравматичні стресові розлади здебільшого вивчали за рубежем [12; 19]. Існують поодинокі закордонні дослідження впливу трудової міграції на психологічне благополуччя та задоволеність життям мігрантів [21], в той час як в Україні таких досліджень не знайдено. Дослідження задоволеності життям набуває особливого значення, оскільки отримані результати дозволять виявляти та втручатися в групи соціального ризику.

Мета дослідження - представлення результатів емпіричного дослідження загальної задоволеності життям жінок-трудових мігранток в Італії.

Матеріали і методи дослідження: теоретичні - аналіз, порівняння й узагальнення наукової літератури з проблеми дослідження; емпіричні - «Шкала задоволеності життям» Е. Дінера (адаптація Є.М. Осіна, Д.О. Леонтьєва).

Виклад основного матеріалу. Благополуччя, задоволення i щастя викликають зростаючу зацікавленість у науковців різних галузей знань, зокрема стали предметом численних психологічних досліджень [16; 17; 22]. У зарубіжній психології широке визнання отримала концепція, розроблена Е. Дінером і його колегами в руслі досліджень суб'єктивного благополуччя особистості. Відповідно до неї задоволеність життям розглядається як когнітивний компонент суб'єктивного благополуччя, що не змішується з афективними компонентами. Задоволеність визначається як глобальна оцінка реального життя через призму суб'єктивних стандартів «хорошого життя», які конструюються самостійно або засвоюються в готовому вигляді з соціального оточення. Загальний рівень задоволеності в кожен конкретний момент часу свідчить про ступінь розбіжності між життєвою реальністю і особистими стандартами «хорошого життя» [15]. Людина задоволена, коли майже немає розриву між реальним та ідеальним або тим, що вона вважає заслуженим. Незадоволеність, у свою чергу, є результатом істотного розриву між даниною і ідеалом, а також може виникати із співставлення себе з іншими людьми.
Відповідно до теорії соціальних порівнянь середній показник задоволеності повинен наближатись до середнього значення. Однак подальші дослідження показали, що на практиці все по іншому - у розвинених індустріальних країнах зазвичай частка задоволених життям людей істотно перевищує частку невдоволених, а в США вона складає 85\% [7]. Що стосується українців, то, за даними нового дослідження, проведеного Київським міжнародним інститутом соціології, майже однакова кількість українців як задоволена своїм життям (48\%), так і незадоволена (55\%). Основним чинником, що визначає їх задоволеність, $€$ фінансове становище. Більш заможні українці частіше відзначають, що вони задоволені тим, як складається їх життя, аніж бідніші. Найбільше людей не влаштовує рівень добробуту, безпеки та впевненість у майбутньому. Так, своєю матеріальною забезпеченістю не задоволені 57\% респондентів, рівнем впевненості в завтрашньому дні - 62\%, безпекою в Україні - 64\% [6]. Міграція при цьому може розглядатися як один із способів відновлення суб'єктивного благополуччя. Так, трудова міграція зазвичай мотивована бажанням індивідуума отримати більш високооплачувану роботу, для того щоб покращити житлові умови своєї сім'ї, купити автомобіль, накопичити кошти для оплати навчання дітей у вищих навчальних закладах, задовільнити інші поточні життєві потреби.

У Світовому міграційному звіті - 2018 вперше представлено глобальну картину здобутків та втрат з точки зору самих мігрантів. Отримані дані свідчать про те, що найбільший приріст благополуччя пов'язаний з міграцією в багаті країни. Так, мігранти, які переїжджають з однієї розвинутої країни в іншу, повідомили про найвищий рівень задоволеності життям, фінансової та особистої безпеки, а також краще здоров'я. Те ж саме стосується людей, які мігрували із заможнішої країни до біднішої, - вони могли досягти відносно вищого положення у суспільстві [24].

Щодо міграції з бідних країн в більш розвинуті, то британське дослідження акцентує увагу на тому, що мігранти навряд чи зможуть досягти там більшого щастя, хоча їхнє життя може значно покращитися в порівнянні зі співвітчизниками вдома. Міграція до заможнішої країни часто передбачає нижчий соціальний статус - мігранти стикаються з відчуженістю та маргіналізацією, що проявляється через обмеження реалізації суспільних ролей та відсутність належного доступу до основних інституцій суспільного життя (охорона здоров'я, освіта, неможливість брати участь у виборах тощо) [5, с. 125].

Ще однією проблемою є невизнання дипломів громадян інших країн в країні призначення, 
зокрема в Італії. Так, українки в Італії опиняються на нижчому щаблі суспільної піраміди, оскільки, маючи відповідний рівень освіти та попередній професійний досвід, можуть претендувати тільки на низькокваліфіковану роботу в секторі домашнього господарства та догляду [26, с. 171]. Дослідники все частіше звертають увагу на феномен «втрати мізків» заробітчанками (brain waste), коли останні свідомо знецінюють свої попередні кваліфікації та досвід [10]. За даними Міністерства праці та соціальної політики в Італії в 2016 році, 22\% українських заробітчанок свого часу закінчили вищі навчальні заклади, а 70\% мали середню освіту [25]. Якщо порівнювати українських іммігрантів з іншими іммігрантами з європейських країн, які не є членами ЄС, то лише $12 \%$ останніх досягли цього рівня, що свідчить про відносно високий рівень освіченості українок. Досить тривожним залишається факт, що кожна п'ята українка-заробітчанка має вищу освіту. Вчені зазначають, що саме мігранти з вищою освітою можуть мати завищені очікування та важче сприймати нову реальність із складними умовами життя [14].

Результати зарубіжних досліджень свідчать, що час проведений за кордоном може впливати на загальну задоволеність життям. Виявлено, що рівень щастя мігрантів відчутно зростає та не змінюється протягом перших п'яти років після переїзду. Однак зі збільшенням терміну проживання в новій країні мігранти починають оцінювати своє становище більш критично. Зокрема, порівнюючи свої доходи уже із доходами зазвичай багатшого корінного населення, а не своїх співвітчизників на батьківщині, вони відчуватимуть меншу задоволеність життям [24]. Відтак суб'єктивне благополуччя залишатиметься нижче середнього, що знову призведе до порушення балансу між цінностями, мотивами і можливостями їх задоволення [13].

Результати інших досліджень свідчать, що мігранти, які проживають більше 10 років в новій країні, будуть досить задоволені своїм життям. За цей час вони опановують іноземну мову та успішно інтегруються на ринку праці у них високий рівень зайнятості, вони рідше працюють на тимчасових або низькокваліфікованих роботах, відтак мають кращі доходи. Однак, незважаючи на те, що матеріальне становище трудових мігрантів покращується з часом, еволюція інших аспектів їхнього життя може бути значно складнішою [20].

Основною гіпотезою емпіричного дослідження було припущення про те, що задоволеність життям у жінок-трудових мігранток $€$ різною залежно від рівня освіти та терміну перебування в Італії. Для діагностики було використано методику «Шкала задоволеності життям» Е. Дінера [4]. Вказана методика вимірює когнітивну оцінку відповідності життєвих обставин очікуванням індивіда і відображає загальну міру внутрішньої гармонії і психологічної задоволеності [8].

Емпіричне дослідження проводилось у Північній Італії протягом 2018-2019 років. У дослідженні взяли участь 200 жінок-трудових мігранток віком від 30 до 79 років. Дослідження проведено за підтримки Італійського уряду (Посольство Італії в Україні, Протокол № 1299 від 8 серпня 2018 року).

у 55 жінок - трудових мігранток була середня базова освіта (27,5\%), у 102 - середня спеціальна (неповна вища) (51\%) та у 43 вища $(21,5 \%)$. Термін перебування до 4-х років відзначили 22 жінки (11\%), від 5 до 9 років 29 жінок (14,5\%), від 10 до 14 років - 55 жінок $(27,5 \%)$ та більше 15 років - 94 жінки $(47 \%)$. Більшість жінок (97\%) мали дітей.

Виявлено, що в загальному 91 жінка задоволена своїм життям (45,5\%) та 103 жінки незадоволені своїм життям (51,5\%) (Рис. 1).

Примітним $\epsilon$ те, що приблизно однакова частка жінок оцінює власне життя як в позитивному, так і в негативному ракурсі. Отже, в загальному рівень благополуччя жінок-заробітчанок $є$ посереднім після працевлаштування за кордоном. Наші результати перегукуються з результатами, отриманими Київським

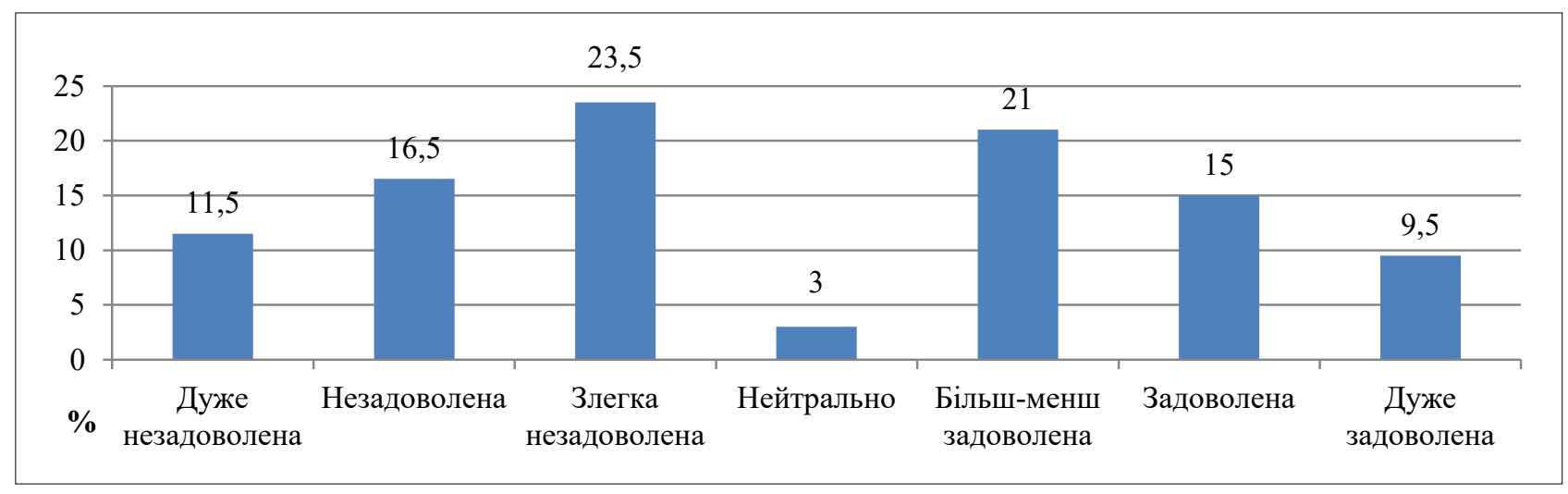

Рис. 1. Задоволеність життям у жінок трудових-мігранток в Італії 
міжнародним інститутом соціології, про що вже згадувалось вище.

За результатами дослідження виявлено, що більшою мірою задоволені життям жінки із середньою та вищою освітами (34,5\% та 32,6\% відповідно). Натомість лишень у 15,7\% жінок із середньою спеціальною освітою високий рівень задоволеності життям, у більшості жінок з такою освітою (53\%) середній рівень. Слід зазначити, що більше жінок із середньою спеціальною та вищою освітами мають низький рівень задоволеності життям, ніж жінок із середньою освітою (31,3\%, 30,2\% та 20\% відповідно). Отже, отримані дані вказують на те, що більш освічені жінки - трудові мігрантки менш щасливі.

Отримані дані збігаються з результатами інших дослідників [11]. На їхню думку, освіта приносить відносну незадоволеність, що перевищує ефект від здобуття матеріальних благ. Вчені пояснюють це тим, що дискримінаційні ситуації та нерівність на робочих місцях $\epsilon$ більш стресовими для освічених мігрантів. Існує чіткий розрив між задоволеністю життям мігрантів з базовою (9 років або менше) і вищою освітами, оцінки коефіцієнтів свідчать про те, що тягар заробітчанства помітно зростає із наявністю вищої освіти.

Аналіз отриманих даних показав, що у більшості жінок 3 коротким терміном перебування в Італії (до 4-х років) переважно середній рівень задоволеності життям (63,6\%) (Табл. 1). Високий та низький рівні - у однаково низького відсотка жінок. Посередній результат можна пояснити з однієї сторони особливостями соціально-психологічної адаптації людини в іноетнічному середовищі, а з іншої - особистісними чинниками.

Так, наважуючись на переїзд, більшість трудових мігранток вважає, що це єдине правильне вирішення їхніх основних сімейних проблем, і тому вони готові їхати за кордон, не знаючи мови нової країни, її культури та традицій. 3 моменту прибуття в нову країну жінок починаються труднощі 3 входженням та облаштуванням в новому суспільстві, з ознайомленням з новими політичними, правовими, економічними, соціально-психологічними та культурними аспектами. В іншій культурі заробітчанки змушені відмовитись від попереднього способу життя, прийняти нові правила та зразки поведінки, соціальні норми.

У перший період трудової міграції жінки погоджуються на будь-яку низькооплачувану роботу, зазвичай доглядальницею, яка $€$ фізично та емоційно виснажливою. Жінки часто працюють без вихіднихта відпочинку, нехтуючи своїм здоров'ям, заощаджують на найнеобхіднішому, аби заробити грошей і забезпечити потреби родини в Україні. О. Федюк наголошує, що жінки-заробітчанки таким чином виконують свою «місію», тобто гарантують економічний добробут власної родини, зокрема дітей, відкладаючи власне благополуччя [18]. Основна роль для таких жінок - бути матір'ю, навіть якщо їх діти є дорослими і уже $є$ внуки [23]. Таким чином, жінки не можуть вказати, що задоволені життям, оскільки їхні персональні потреби не задовільняються належним чином, але і не можуть вказати на неблагополуччя, адже допомагають сім'ї.

На думку І. Маркова, зі збільшенням терміну перебування в Італії в трудових мігрантів все більше проявляється спрямованість на задоволення особистих життєвих потреб, духовних запитів, пов'язаних із пізнанням нової країни, її культури, спостерігається тенденція до самореалізації. Українці потрохи втягуються в італійське життя. Для багатьох із них стають звичними його умови (пошана людських прав, розвинута інфраструктура). Цьому сприяє також у цілому толерантне ставлення італійців до мігрантів і, зокрема, українців, яких відзначає культурна спорідненість з європейцями, працьовитість тощо [2]. Відповідно, жінки більшою мірою відзначають власне благополуччя. Так, майже у третини жінок, що перебували в Італії від 5 до 9 років та від 10 до 14 років, високий рівень задоволеності життям.

Однак слід відзначити те, що з більшим терміном перебування збільшується кількість жінок, які не задоволені життям. Так, майже третина жінок, які працювали в Італії більше 10-14 років та більше 15 років, відзначили низьку задоволеність життям (32,7\% та 28,8\% відповідно). Слід наголосити, що трудова міграція часто спричиняє значний стрес для особистості трудової мігрантки. Негативні переживання можуть призводити до психічних та психосоматичних розладів у жінок. Учені

\section{Задоволеність життям жінок-трудових мігранток залежно від терміну перебування в Італії}

Таблиця 1

\begin{tabular}{|l|c|c|c|c|}
\hline \multirow{2}{*}{$\begin{array}{c}\text { Рівні } \\
\text { задоволеності } \\
\text { життям }\end{array}$} & \multicolumn{4}{|c|}{ Термін перебування } \\
\cline { 2 - 5 } & До 4-х років, \% & $\mathbf{5 - 9}$ років, \% & $\mathbf{1 0 - 1 4}$ років, \% & Більше 15 років, \% \\
\hline Високий & 18,2 & 31 & 27,3 & 22,3 \\
\hline Середній & 63,6 & 44,8 & 40 & 48,9 \\
\hline Низький & 18,2 & 24,2 & 32,7 & 28,8 \\
\hline
\end{tabular}


трактують дане нездужання як «італійський синдром» [9].

Жінки-заробітчанки із багаторічним стажем після повернення на батьківщину часто стикаються 3 гострими соціально-психологічними проблемами, пов'язаними із втратою соціально-адаптивних механізмів. Спершу, від'їжджаючи за кордон, у них в планах було попрацювати лише рік-два з метою заробити достатньо грошей для придбання житла, навчання дітей, забезпечення батьків тощо. Однак їхня праця в Італії затягнулася на роки, життя для них зупинилося до тих пір, допоки вони не повернуться до своєї сім'ї і почнуть жити знову [18, с. 297-298]. Після вороття на батьківщину, намагаючись відродити свої взаємини з рідними та близькими, вони стикаються із труднощами: шлюб перетворився в дистанційний, діти відвикли від них, сприймають як «банкомат» - гроші беруть як належне; звичні соціальні зв'язки уже давно втрачені. Побувши деякий час вдома і не знайшовши тут уже для себе місця, заробітчанки прагнуть назад до вже звичної проте все ще чужої Італії. На думку І. Маркова, «середовищ, щодо яких відбувається самовизначення трудових мігрантів, тепер два: в одному з них він «живе», до іншого «повертається» [2].

Висновки. Існує недосліджений взаємозв'язок у психологічній літературі між трудовою міграцією та задоволеністю життям. Так, прагнення до щастя може бути рушієм міграційного рішення. I навпаки, трудова міграція також може вплинути на щастя особистості. 3 одного боку, заробітчани можуть отримати більш високий дохід, однак можуть зіткнутися з рядом проблем, що в кінцевому результаті визначатиме їх задоволеність життям. Згідно із проведеним дослідженням можна констатувати, що задоволеність життям жінок-трудових мігранток відчутно не зростає після виїзду за кордон: кількість щасливих та нещасливих жінок є майже однаковою. Отже, трудова міграція призводить до значущих змін у житті вимушених трудових мігрантів, може як покращувати, так і погіршувати якість їх життя.

Припущення про те, що задоволеність життям у жінок-трудових мігранток $є$ різною залежно від рівня освіти та терміну перебування в Італії, підтвердилося. Тенденція до задоволеності життям прослідковується в жінок із середньою та вищою освітами та тих, що перебували в Італії від 5 до 9 років та від 10 до 14 років. Тенденція до незадоволеності життям прослідковується у жінок із середньою спеціальною та вищою освітами, а також тих, які працювали в Італії більше 10-14 років та більше 15 років. Однак наразі недостатньо інформації про те, наскільки значущими $\epsilon$ дані фактори, чи різниця в рівні задоволеності життям пояснюється іншими чинниками, зокрема пов'язаними з соціодемографічними характеристиками (вік та сімейний статус тощо), типом зайнятості, станом здоров'я, рівнем матеріального доходу та ін. Водночас результати дослідження наштовхують на роздуми про більш складну структуру задоволеності життям, тому очевидно, що однієї методики замало для об'єктивної оцінки. Даний етап $€$ першим у визначеній нами стратегії дослідження психологічного благополуччя жінок-трудових мігранток. У подальшому планується продовження його вивчення.

\section{ЛITЕРАТУРА:}

1. Гаврилишин П. Українська трудова імміграція в Італії (1991-2011 рр.). Івано-Франківськ, 2012. 246 с.

2. Марков І. Українці в Італії: френомен жіночої міграції. Україна модерна. Міжнародний інтелектуальний часопис. 2012. URL : http://uamoderna.com/ $\mathrm{md} / 185$

3. Населення України. Трудова еміграція в Україні / ред. рада: Е.М. Лібанова, О.В. Позняк, О.А. Малиновська. Київ : Ін-т демографії та соціальних досліджень ім. М.В. Птухи НАН України, 2010. 233 с.

4. Осин Е.Н., Леонтьев Д.А. Апробация русскоязычных версий двух шкал экспресс-оценки субъективного благополучия. Материалы III Всероссийского социологического конгресса. Москва : Институт социологии РАН, Российское общество социологов, 2008.

5. Рожновські Б., Брик Д. Стрес, обумовлений еміграцією, і його наслідки для системи цінностей емігрантів. Міграція - виклик XXI століття; за ред. Мацєя Cm. Зємби. Люблін : Видавництво Люблінського католицького університету, 2008. С. 119-142.

6. Сахно Ю. Задоволеність українців різними аспектами життя та тим, як складається життя в цілому. КMIC. 2019. URL : http://kiis.com.ua/?lang=uk r\&cat=reports\&id=882\&page $=1$.

7. Смолева Е.О., Морев М.В. Удовлетворенность жизнью и уровень счастья: взгляд социолога / под науч. ред. д.э.н. А.А. Шабуновой. Вологда : ИСЭРТ $\mathrm{PAH}, 2016.164 \mathrm{c}$.

8. Шелемей О. Діагностика рівня задоволеності життям в жінок-трудових мігранток в Італії. Щастя та цивілізаційний розвиток: збірник матеріалів міжнародної науково-практичної конференчії (Львів, 14-15 листопада 2019 р.). Львів, 2019. С. 247-250.

9. Шелемей О.П. Наслідки заробітчанського «щастя»: «італійський синдром» / Щастя та сучасне суспільство: збірник матеріалів міжнародної наукової конференції (Львів, 20-21 березня 2020 р.). Львів : СПОЛОМ, 2020. С. 239-242.

10. Юрценюк О. Психічні розлади та психологічні проблеми жінок-трудових мігрантів. БДМУ. 2015. URL : https://www.bsmu.edu.ua/blog/3993-psihichnirozladi-ta-psihologichni-problemi-zhinok-trudovihmigrantivl.

11. Akay A., Giulietti C., Robalino J.D., \& Zimmermann K.F. Remittances and well-being among Rural-toUrban Migrants in China, mimeo. 2013.

12. Anjara S.G., Nellums L.B., Bonetto C., \& Van Bortel T. Stress, health and quality of life of female 
migrant domestic workers in Singapore: a crosssectional study. BMC Womens Health. 2017. 17(1). 98. URL : https://doi.org/10.1186/s12905-017-0442-7

13. Chindarkar N. Is subjective well-being of concern to potential migrants from Latin America? Social Indicators Research. 2014. 115(1). P. 159-182.

14. Démurger S., Li S., \& Xu H. Internal migration, family living arrangements and happiness in China. 2013. URL : https://www.hhs.se/contentassets/c9558 a10642a49d9815e5b09f189b9dc/internal-migrationfamily-living-arrangements-and-happiness-in-china.pdf.

15. Diener E., Oishi Sh., \& Lucas R. Personality, Culture and Subjective Well-Being: Emotional and Cognitive Evaluations of Life. Annual Review of Psychology. 2003. 54. P. 403-425.

16. Diener E., \& Seligman M.E. Beyond Money: Toward an Economy of Well Being. Psychological Science in the Public Interest. 2004. 5(1). P. 1-31. URL : https://doi.org/10.1111/j.0963-7214.2004.00501001.x.

17. Extremera N., José M., S., \& Fernández-Berrocal P. Trait Meta-Mood and Subjective Happiness: A 7-week Prospective Study. Journal of Happiness Studies. 2011. 12. P. 509-517. URL : https://doi.org/10.1007/ s10902-010-9233-7.

18. Fedyuk O. Images of transnational motherhood: The role of photographs in measuring time and maintaining connections between Ukraine and Italy. Journal of Ethnic and Migration Studies. 2012. 38(2). P. 279-300. URL : https://doi:10.1080/13691 83X.2012.646422.

19. Hovey J.D. Acculturative stress, depression, and suicidal ideation in Mexican immigrants. Cultural Diversity and Ethnic Minority Psychology. 2000. 6. P. 134-151. URL : http://dx.doi.org/10.1037/1099-9809.6.2.134.
20. How's Life? Measuring Well-being. OECD Publishing, Paris. 2017. URL : https://doi.org/10.1787/ how life-2017-en.

21. Jibeen T., \& Khalid R. Predictors of Psychological well-being of Pakistani Immigrants in Toronto, Canada. International Journal of Intercultural Relations. 2010. 34. 5. P. 452-464. URL : https://doi.org/10.1016/j. ijintrel.2010.04.010.

22. Keyes C.L.M., Shmotkin D., \& Ryff C.D. Optimizing well-being: The empirical encounter of two traditions. Journal of Personality and Social Psychology. 2002. 82(6). P. 1007-1022. URL : https:// doi.org/10.1037/0022-3514.82.6.1007

23. Marchetti S., \& Venturini A. Mothers and grandmothers on the move: Labour mobility and household strategies of Moldovan and Ukrainian migrant women in Italy. International Migration. 2013. 52(5). P. 111-126.

24. Ray J., \& Esipova N. Are Migrants Happier After They Move? GALLUP blog. 2018. URL : http:// news.gallup.com/opinion/gallup/230639/migrantshappiermove.aspx?g_source=link_NEWSV9\&g medium=TOPIC\&g_campaign=item_\&g_content=Are\% 2520Migrants\%2520Happier\%2520After\%2520They\% 2520Move\%3f.

25. The Ukrainian community. Annual Report on the presence of Migrants in Italy. Executive Summary. 2016. / Edited by Ministero del Lavoro e delle Politiche Sociali.

26. Vianello F.A. Migration of Ukrainian Nationals to Italy: Women on the Move. In: Fedyuk O., Kindler M. (eds) Ukrainian Migration to the European Union. IMISCOE Research Series. Springer, Cham. 2016. URL : https://doi.org/10.1007/978-3-319-41776-9_10. 